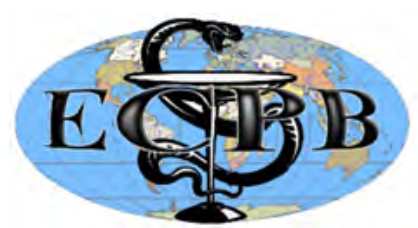

"ЕКСПЕРИМЕНТАЛЬНА ТА КЛІНІЧНА ФІЗІОЛОГІЯ І БІОХІМІЯ" "EXPERIMENTAL AND CLINICAL PHYSIOLOGY AND BIOCHEMISTRY" Науково-практичний журнал/Scientific-practical journal

Наукові статті / Research article ECPB 2018, 2(82): 15-20. https://doi.org/

\title{
System Approach to Regulation of the Harmful Influence of Medicines in the Conditions in the Manufacturing Process and Environment
}

\author{
B.P. KUZMINOV, T.S. ZAZULYAK., O.I. HRUSHKA, A.B. KUZMINOV, \\ I.A. SHVETS, A.A. BREJDAK \\ Danylo Halytsky Lviv National Medical University, Lviv, Ukraine
}

E-mail: expertiza39@gmail.com

The main feature of medicines is high biological activity of their active components. Next to the positive medicinal effects, the active components of medications can have negative effects. Moreover, they can also show the biological influence on the organism of workers involved in the manufacturing process, on population and environment [3, 5, 6, 15]. This feature allows to categorize the medicines manufacturing as the ecologically dangerous process. It dictates the necessity to prevent negative influence of the active components of medicines on the working conditions as well as their entering into the atmospheric air, water, soil $[3,8]$. However, such influence refers mostly to the air in the working area and inhabited places located in the neighbourhood of enterprises, modern pharmaceutical manufacturing process flowsheets almost eliminate the contamination of aquatic objects and soils on the territories adjoined to the enterprises.

Medicine manufacturing process is regulated by Ukrainian legislation and includes obligatory regulation of allowable amount of their active components in the air in the working area $[4,7,8,12]$. Thus, creation of the sanitary standards of these components in the atmospheric air is extremely important. On the other hand, development of the sanitary standards of chemicals in the different environment objects is often based on the systemic approach that has methodologically unified toxicological basis $[4,9,10]$. This fact has defined a purpose and ways of solution of the task set. Objective: to regulate the amount of allowable active components of some drugs in the working area and atmospheric air of the inhabited places on the basis of systemic approach and to conduct the research of the air in order to determine the accordance of the levels of chemicals with the hygienic norms.

Materials and methods. The components of medicines for which development of regulations of allowable content in the working area and atmospheric air has been made: bismuth citrate, L-lysine aescinat, procaine hydrochloride, diphenhydramine hydrochloride, cyanocobalamin. The research has been performed to the order of Halychfarm OJSC (Lviv, Ukraine) on the stage of applying of the corresponding medicines to manufacture.

The following methodical documents have been taken as a basis $[1,2,4$, $11,14]$. Thus the methodical schemes of creation of sanitary standards of chemicals in the working area and atmospheric air of inhabited places have been theoretically analysed and a scheme for simultaneous creation of both norms has been created. The toxicological experiments have been conducted at the warm-blooded laboratory animals within the framework of bioethical

(c) Kuzminov B.P., Zazulyak T.S., Hrushka O.I. et al., 2018 
norms in accordance with the International Guiding Principles for Biomedical Research Involving Animals (WHO, 1984), and European Convention for the Protection of Vertebrate Animals used for Experimental and Other Scientific Purposes [13].

Results and discussion. Hygienic regulations of allowable hazardous chemical substance level (including pharmaceutical drugs components) in the working area and atmospheric air according to the Ukrainian legislation include a term - maximum allowable concentration (MAC), $\mathrm{mg} / \mathrm{m}^{3}$ or approximately safe level of impact (ASLI), $\mathrm{mg} / \mathrm{m}^{3}[8,12]$.

Maximum allowable concentration of harmful substances in the working area air is a concentration that in the case of daily work (except for days off) for 8 hours or other duration, but not more than 41 hours a week, can not cause diseases or rejections of health during the working life that can be revealed by the modern examination methods in the working process or life of this and next generations.

The maximum allowable concentration (MAC) of harmful substances in atmospheric air of the inhabited places is means the concentration under which direct or indirect unfavourable influence on this and future generation does not occur during one's all life, the working capacity is not lowered, state of health and sanitary and everyday life conditions do not become worse.

Approximately safe level of impact (ASLI) of the harmful chemical substances is a temporal hygienic norm of the amount of chemical substance set on the basis of the brief researches and calculated according to the parameters of toxicometry as well as the physical and chemical properties of compound.

According to the results of analysis of methodical schemes of sanitary standard creation operated in Ukraine, the safe levels of the medicines in the working area and atmospheric air are based on experimental determination of minimum concentration (doses) of the substance that cause the changes in the organism of test animals that exceed the limits of physiological adaptive reactions. Thus the methodical schemes do not differ fundamentally and can be combined into following stages:

1. Analysis of physical and chemical properties data, creation of the methods of measuring implementation (MMI) of the substances concentrations in the air.

2 . The investigation of parameters of acute medicine toxicity and the effect on the laboratory animals under the influence of a single dose upon introduction into the stomach that means a median lethal dose $\left(\mathrm{LD}_{50}\right)$, at inhalation - a median lethal concentration $\left(\mathrm{CL}_{50}\right)$, and also single action threshold - $\mathrm{Lim}_{\mathrm{ac}}$.

3. Determination of cumulative properties of the substances.

4. Research of the local skin effect and mucous membrane of the eye in animals.

5. Determination of the harmful effect threshold at the chronic entering of the substances into organism (4 hours during 4 months for MAC in the working area air and 24 hours during 2-4 months for MAC in the atmospheric air of the inhabited places). The task is to determine the Lim threshold concentration that causes the biologically meaningful changes of the integral and specific indices in the organism of the animals

6. Determination of functional, biochemical, morphological, immunological and other indices characterizing ability to cause general or specific toxic effects. Determination of the future effect results (gonadotropic influence, embryotropic influence, mutagenic and carcinogenic effects).

7. Determination of the hygienic norm of the allowable content of the substance in the working area and atmospheric air.

As a result of the conducted researches the character of biological action of the bismuth citrate, L-lysine aescinat, procaine hydrochloride, diphenhydramine hydrochloride, cyanocobalamin on the laboratory animals organism has been determined (Table 1). 
Table 1

Character of biological effect of the the bismuth citrate, L-lysine aescinat, procaine hydrochloride, diphenhydramine hydrochloride, cyanocobalamin on the organism of the laboratory animals in the conditions of a toxicological experiment

\begin{tabular}{|c|c|c|}
\hline $\begin{array}{c}\text { Name of } \\
\text { substance }\end{array}$ & Way of action & Toxicity parameters (white rats) \\
\hline Bismuth citrate & $\begin{array}{l}\text { Central nervous system stimu- } \\
\text { lation; reduction of red corpus- } \\
\text { cles and haemoglobin amount } \\
\text { in blood; cause of the sharply } \\
\text { expressed irritating action on } \\
\text { mucous membranes; strongly } \\
\text { expressed cumulative activity; } \\
\text { no teratogenic and embryotoxic } \\
\text { action }\end{array}$ & $\begin{array}{l}\mathrm{LD}_{50}-\text { from } 8350.0 \mathrm{mg} / \mathrm{kg} \text { to } \\
11800 \mathrm{mg} / \mathrm{kg} \\
\mathrm{CL}_{50}-4637.2 \mathrm{mg} / \mathrm{m}^{3} \\
\mathrm{Lim}_{\mathrm{ac}}-452.2 \mathrm{mg} / \mathrm{m}^{3} \\
\text { Accumulation coefficient }-2.41 \\
\text { (highly accumulative substance) } \\
\mathrm{Lim}_{\text {ch }}-2.0 \mathrm{mg} / \mathrm{m}^{3}(4 \text { hours during } \\
4 \text {-month experiment) }\end{array}$ \\
\hline L-lysine aescinat & $\begin{array}{l}\text { Negative influence on central } \\
\text { nervous system and urinary } \\
\text { organ; weak local skin irritating } \\
\text { action and sharply expressed } \\
\text { damaging action on mucous } \\
\text { membranes; formation of allergic } \\
\text { and organism's autoimmune } \\
\text { reactions; no teratogenic and } \\
\text { embryotoxic action }\end{array}$ & $\begin{array}{l}\mathrm{LD}_{50}-\text { from } 770.0 \mathrm{mg} / \mathrm{kg} \text { to } 815.0 \mathrm{mg} / \mathrm{kg} \\
\mathrm{CL}_{50}-1740.0 \mathrm{mg} / \mathrm{m}^{3} \\
\mathrm{Lim}_{\mathrm{ac}}-51.6 \mathrm{mg} / \mathrm{m}^{3} \\
\text { Accumulation coefficient - > } 12.0 \text { (low } \\
\text { accumulative substance) } \\
\text { Lim }_{\text {ch }}-18.0 \mathrm{mg} / \mathrm{m}^{3} \text { (4 hours } 4 \text {-month } \\
\text { experiment) }\end{array}$ \\
\hline $\begin{array}{l}\text { Procaine } \\
\text { hydrochloride }\end{array}$ & $\begin{array}{l}\text { Central nervous system blocking } \\
\text { and weak local irritating action; } \\
\text { middle-expressed irritating } \\
\text { action at mucous membrane } \\
\text { contact; allergen effect on the } \\
\text { organism; no teratogenic and } \\
\text { embryotoxic action }\end{array}$ & $\begin{array}{l}\mathrm{LD}_{50}-\text { from } 1220.0 \mathrm{mg} / \mathrm{kg} \text { to } \\
1470.0 \mathrm{mg} / \mathrm{kg} . \\
\mathrm{CL}_{50}-3000.0 \mathrm{mg} / \mathrm{m}^{3} \\
\mathrm{Lim}_{\mathrm{ac}}-50.0 \mathrm{mg} / \mathrm{m}^{3} \\
\text { Accumulation coefficient - > } 8.2 \text { (low } \\
\text { accumulative substance) } \\
\mathrm{Lim}_{\text {ch }}-5.6 \mathrm{mg} / \mathrm{m}^{3} \text { (4 hours } 2 \text {-month } \\
\text { experiment) }\end{array}$ \\
\hline $\begin{array}{l}\text { Diphenhydramine } \\
\text { hydrochloride }\end{array}$ & $\begin{array}{l}\text { H1 receptor blockers, suppression } \\
\text { of central nervous system, } \\
\text { change of the myocardium } \\
\text { metabolism processes; weak } \\
\text { local skin irritating action } \\
\text { and expressed irritating } \\
\text { action at mucous membrane } \\
\text { contact; formation of allergic } \\
\text { and organism's autoimmune } \\
\text { reactions; no teratogenic and } \\
\text { embryotoxic action }\end{array}$ & $\begin{array}{l}\mathrm{LD}_{50}-\text { from } 400.0 \mathrm{mg} / \mathrm{kg} \text { to } \\
850.0 \mathrm{mg} / \mathrm{kg} \\
\mathrm{Lim}_{\mathrm{ac}}-30.0 \mathrm{mg} / \mathrm{m}^{3} \\
\mathrm{CL}_{50}-1050.0 \mathrm{mg} / \mathrm{m}^{3} \\
\text { Accumulation coefficient - }>8.2 \text { (low } \\
\text { accumulative substance) } \\
\mathrm{Lim}_{\text {ch }}-1.85 \mathrm{mg} / \mathrm{m}^{3} \text { (4 hours } 2 \text {-month } \\
\text { experiment) }\end{array}$ \\
\hline Cyanocobalamin & $\begin{array}{l}\text { Influence on the hematogenesis } \\
\text { system, central nervous system; } \\
\text { coagulation system activation; } \\
\text { resorptive and toxic effects and } \\
\text { weak local irritating action at } \\
\text { skin contact; weak irritating } \\
\text { action at mucous membrane } \\
\text { contact; formation of allergic } \\
\text { and organism's autoimmune } \\
\text { reactions; no teratogenic and } \\
\text { embryotoxic action }\end{array}$ & $\begin{array}{l}\mathrm{LD}_{50}-\text { from } 2800.0 \mathrm{mg} / \mathrm{kg} \text { to } \\
3480.0 \mathrm{mg} / \mathrm{kg} . \\
\mathrm{Lim}_{\mathrm{ac}}-1500.0 \mathrm{mg} / \mathrm{m}^{3} \\
\mathrm{CL}_{50}-20494.0 \mathrm{mg} / \mathrm{m}^{3} \\
\text { Accumulation coefficient - > } 12.8 \text { (low } \\
\text { accumulative substance) } \\
\text { Limch }-0,1 \mathrm{mg} / \mathrm{m}^{3} \text { (4 hours } 4 \text {-month } \\
\text { experiment) }\end{array}$ \\
\hline
\end{tabular}

Obtained figures of the sanitary regulations and methods of measuring of the active component concentrations in the working area and atmospheric air are depicted in the table 2 . Thus the figures of the sanitary standards and MMI of medicines concentrations in the working area air have been approved 
by the Ministry of Health of Ukraine, and in the atmospheric air - as for now they are in the process of approval.

Table 2

Regulations of the allowable amount of active components of medicines in the working area and atmospheric air and the methods for measuring the concentrations of medicines

\begin{tabular}{|c|c|c|c|}
\hline \multirow{2}{*}{ Name of substance } & \multicolumn{2}{|c|}{ Hygienic norm } & \multirow{2}{*}{$\begin{array}{l}\text { Methods of measuring } \\
\text { implementation }\end{array}$} \\
\hline & $\begin{array}{l}\text { In the working } \\
\text { area air* }\end{array}$ & \begin{tabular}{|c|} 
In the atmospheric \\
air
\end{tabular} & \\
\hline $\begin{array}{l}\text { Bismuth citrate } \\
\text { (citric acid bismuth) }\end{array}$ & $\begin{array}{l}\text { MAK } 1.0 \mathrm{mg} / \mathrm{m}^{3} \\
\text { hazard class } 2 \\
\text { marked "+" }\end{array}$ & MAK $0.02 \mathrm{mg} / \mathrm{m}^{3}$ & $\begin{array}{l}\text { MMI of citric acid bis- } \\
\text { muth mass concentration } \\
\text { in the working area air } \\
\text { by a photometric method. } \\
\text { MMI no. } 081 / 12-0250-05 \\
\text { dated } 28 / 11 / 2005\end{array}$ \\
\hline L-lysine aescinat & $\begin{array}{l}\text { MAK } 2.0 \mathrm{mg} / \mathrm{m}^{3} \\
\text { hazard class } 3 \\
\text { marked "+" }\end{array}$ & MAK $0,04 \mathrm{mg} / \mathrm{m}^{3}$ & $\begin{array}{l}\text { MMI of L-lysine aescinat } \\
\text { mass concentration in } \\
\text { the working area air by } \\
\text { the photometric method. } \\
\text { MMI no. } 081 / 12-0412-07 \\
\text { dated } 22 / 02 / 2007 \\
\end{array}$ \\
\hline $\begin{array}{l}\text { Dimedrol (diphenhydramine } \\
\text { hydrochloride) }\end{array}$ & $\begin{array}{l}\text { ASLI } 0.2 \mathrm{mg} / \mathrm{m}^{3} \\
\text { marked "+" }\end{array}$ & ASLI $0.006 \mathrm{mg} / \mathrm{m}^{3}$ & $\begin{array}{l}\text { MMI of dimedrol mass } \\
\text { concentration (diphenhy- } \\
\text { dramine hydrochloride) } \\
\text { in the working area air } \\
\text { by the photometric meth- } \\
\text { od. MMI no. 081/12-0601- } \\
09 \text { dated } 23 / 02 / 2009 \\
\end{array}$ \\
\hline $\begin{array}{l}\text { Novocaine } \\
\text { (procaine hydrochloride) }\end{array}$ & $\begin{array}{l}\text { MAK } 0.5 \mathrm{mg} / \mathrm{m}^{3} \\
\text { hazard class } 2 \\
\text { marked "+" }\end{array}$ & MAK $0.01 \mathrm{mg} / \mathrm{m}^{3}$ & $\begin{array}{l}\text { MMI of novocaine mass } \\
\text { concentration of (pro- } \\
\text { caine hydrochloride) in } \\
\text { the working area air by } \\
\text { a photometric method. } \\
\text { MMI no. } 081 / 12-0602-09 \\
\text { dated } 23 / 02 / 2009 \\
\end{array}$ \\
\hline Cyanocobalamin & $\begin{array}{l}\text { MAK } 0.05 \mathrm{mg} / \mathrm{m}^{3} \\
\text { hazard class } 1 \\
\text { marked "+" }\end{array}$ & MAK $0,002 \mathrm{mg} / \mathrm{m}^{3}$ & $\begin{array}{l}\text { MBB of cyanocobalamin } \\
\text { mass concentration in } \\
\text { the working area air by } \\
\text { the spectrophotometric } \\
\text { method. MMI no. 081/12- } \\
\text { 0603-09 dated 23/02/2009 }\end{array}$ \\
\hline
\end{tabular}

Note: * - 1) hazard class of the substances determined in accordance with GOST 12.1.007-76 [8]; 2) mark " + " indicates the necessity to protect the skin and eyes; 3) mark " $\mathrm{A}$ " indicates the ability to cause allergic diseases in manufacturing conditions.

As a result of the sanitary-chemical researches, the ability of the compounds to enter the working area has been confirmed. Moreover, it has been determined that the concentration of bismuth citrate at the workplaces can vary from $0.21 \mathrm{mg} / \mathrm{m}^{3}$ to $1.59 \mathrm{mg} / \mathrm{m}^{3}$, L-lysine aescinat - from $0.92 \mathrm{mg} / \mathrm{m}^{3}$ to $0.96 \mathrm{mg} / \mathrm{m}^{3}$, procaine hydrochloride - from $0.22 \mathrm{mg} / \mathrm{m}^{3}$ to $0.23 \mathrm{mg} / \mathrm{m}^{3}$, cyanocobalamin - from $0.025 \mathrm{mg} / \mathrm{m}^{3}$ to $0.028 \mathrm{mg} / \mathrm{m}^{3}$. Diphenhydramine hydrochloride has not been detected. In the samples of the air taken at the line of sanitary protective zone of the Halychfarm OJSC (50 m distance from the source of contamination) the bismuth citrate has been detected in the amount of $0.14 \mathrm{mg} / \mathrm{m}^{3}$ and procaine hydrochloride $-0.07 \mathrm{mg} / \mathrm{m}^{3}$. This points out the potential danger of entering medicines the air of the inhabited places. Furthermore, it also shows the actuality of simultaneous introduction of the sanitary 
standards for allowable amount of compounds in the working area and in atmospheric air.

Conclusions. 1. The methodical scheme of a systemic approach for simultaneous regulation of the allowable amount of medicines in the working area and atmospheric air has been created.

2. On the basis of the systemic approach the following values of sanitary standards have been set. In the working area air: bismuth citrate (citric acid bismuth) - MAK $1.0 \mathrm{mg} / \mathrm{m}^{3}$, L-lysine aescinat - MAK $2.0 \mathrm{mg} / \mathrm{m}^{3}$, diphenhydramine hydrochloride - ASLI $0.2 \mathrm{mg} / \mathrm{m}^{3}$, procaine hydrochloride - MAK $0.5 \mathrm{mg} / \mathrm{m}^{3}$, cyanocobalamin - MAK $0.05 \mathrm{mg} / \mathrm{m}^{3}$. In the atmospheric air: bismuth citrate - MAK $0.02 \mathrm{mg} / \mathrm{m}^{3}$, L-lysine aescinat - MAK $0.04 \mathrm{mg} / \mathrm{m}^{3}$, diphenhydramine hydrochloride - ASLI $0.006 \mathrm{mg} / \mathrm{m}^{3}$, procaine hydrochloride - MAK $0.01 \mathrm{mg} / \mathrm{m}^{3}$, cyanocobalamin - MAK $0.002 \mathrm{mg} / \mathrm{m}^{3}$.

3. The sanitary-chemical researches have confirmed the ability of the compounds to enter the air of the working area and inhabited places at the hygienically meaningful levels.

\section{REFERENCES}

1. Доклінічні дослідження лікарських засобів. Методичні рекомендації. За ред. ОК Стефанова: Авіцена; 2001. 528 (Preclinical studies of drugs. Guidelines. Za red. OK Stefanova: Avitsena; 2001. 528). 2. Коваленко ВМ, Стеббанов ОВ, Максимов ЮМ, Трахтенберг IM. Експериментальне вивчення токсичної дії потенщійних лікарських засобів - Доклінічні дослідження лікарських засобів: метод. рекомендації. За ред. чл.-кор. АМН України ОВ. Стефанова. К.: Авіцена; 2001. 74-97 (Kovalenko VM, Stefanov OV, Maksymov YuM, Trakhtenberh IM. Experimental study of toxic effects of potential medicinal products - Preclinical research of medicinal products: Methodical recommendations. Za red. chl.-kor. AMN Ukrainy OV Stefanova. K.: Avitsena; 2001. 74-97). 3. Лакин КМ, Крылов ЮФ. Биотрансформация лекарственных веществ: общие вопросы. М.: Медицина; 1981. 344 (Lakyn KM, Krylov YuF. Biotransformation of medicinal substances: general issues. M.: Medytsyna; 1981. 344). 4. Методы экспериментального исследования по установлению порогов действия промышленных ядов на генеративную функцию с целью гигиенического нормирования: метод. указания № 1744-77. М.; 1978. 36 (Methods of experimental research on the establishment of thresholds for the action of industrial poisons on the generative function for the purpose of hygienic rationing. Methodical instructions № 1744-77. M.; 1978. 36). 5. Нир И, Эдельштейн ЕЛ, Алдисен А. Побочные действия лекарственных средств. Пер. с англ. Под ред. МНГ Дюкса. М.: Медицина; 1983. 560. (Nyr Y, Edel'shtejn EL, Amdysen A. Meyler's side effects of drugs. Per. s anhl. Pod red. MNH Diuksa. M.: Medytsyna; 1983. 560). 6. Обгрунтування гранично допустимих концентрацій лікарських засобів у повітрі робочої зони і в атмосферному повітрі населених місць. Наказ МОЗ України № 544 від 21.10.2005 (Justification of the maximum permissible concentrations of drugs in the air of the working zone and in the atmospheric air of inhabited places. Nakaz MOZ Ukrainy № 544 vid 21.10.2005). 7. Про лікарські засоби. Закон України 123/96-вр. Відомості Верховної Ради України. 1996;22:86 (Pro likars'ki zasoby. Zakon Ukrainy 123/96-vr. Vidomosti Verkhounoi Rady Ukrainy. 1996;22:86). 8. Система стандартов безопасности труда. Вредные вещества. Классификащия и общие требования безопасности. ГОСТ 12.1.007-76. Государственный комитет СССР по стандартам. М.: Изд-во стандартов. 5 (System of safety standards. Harmful substances. Classification and general safety requirements. HOST 12.1.007-76. Hosudarstvennyj komytet SSSR po standartam. M.: Yzdatel'stvo standartov. 5). 9. Трахтенберг IM, Кокшарьова HB. Сучасні аспекти лікарської токсикології: Профілактична токсикологія та медична екологія. Вибрані лекції для науковців, лікарів та студентів. За ред. IM Трахтенберга. К.: Авіцена; 2011. 206-17 (Trakhtenberh IM, Kokshar'ova NV. Modern aspects of drug toxicology: Preventive toxicology and medical ecology. Selected lectures for scientists, doctors and students. Za red. IM Trakhtenberha. K.: Avitsena; 2011: 206-17). 10. Tрахтенберг IM, Коршун МH. Еще раз о соотношении системного и комплексного в гигиеническом нормировании вредных веществ. Сучасні проблеми токсикології. 2010;1:83-6 (Trakhtenberh IM, Korshun MN. Once again on the correlation of systemic and complex in the hygienic regulation of harmful substances. Suchasni problemy toksykolohii. 2010;1:83-6). 11. Трахтенбере IM, Коршун MH. Обоснование безопасных уровней содержания вредных веществ в объектах внешней среды - системное или копмлексное? Сучасні проблеми токсикології. 2007;2:4-8 (Trakhtenberh IM, Korshun $M N$. The rationale for safe levels of harmful substances in environmental objects - is systemic or complex? Suchasni problemy toksykolohii. 2007; 2: 4-8). 12. Штабський БМ, Гжегоцький МP. Ксенобіотики, гомеостаз і хімічна небезпека людини. Львів: Наутілус; 1999. 312 (Shtabs'kyj BM, Gzhehots'kyj MR. Xenobiotics, homeostasis and chemical danger of a person. L'viv: Nautilus; 1999. 312). 13. European Convention for the Protection of Vertebrate Animals used for Experimental and Other Scientific Purposes. Strasbourg, 18.III.1986. 11. 14. Lim RK et al. A method for the evaluation of cumulation and tolerance by the determination of acute and 
subchronic median effective doses. Arch Int Pharmacodyn Ther. 1961;130:336-53. 15. Piening S, Haaijer-Ruskamp FM, de Graeff PA, Straus SM, Mol PG. Healthcare professionals' self-reported experiences and preferences related to direct healthcare professional communications: a survey conducted in the Netherlands. 2012; Nov 1;35(11):1061-72.

Стаття надійшла до редколегї 29.05.2018

\title{
RESEARCH ARTICLE
}

\section{System Approach to Regulation of the Harmful Influence of Medicines in the Manufacturing Process and Environment}

\author{
B.P. KUZMINOV, T.S. ZAZULYAK., O.I. HRUSHKA, A.B. KUZMINOV, \\ I.A. SHVETS, A.A. BREJDAK \\ Danylo Halytsky Lviv National Medical University, Lviv, Ukraine \\ E-mail: expertiza39@gmail.com
}

The manufacturing of medicines is considered as the ecologically dangerous process what dictates the necessity to prevent the negative influence of its active components on the working conditions and air of the inhabited places.

A system approach has included the development of the sanitary regulations for allowable active components of some medicines. Simultaneously the following hygiene standards have been elaborated - in the working area air: bismuth citrate (citric acid bismuth) MAK $1.0 \mathrm{mg} / \mathrm{m}^{3}$, L-lysine aescinat - MAK $2.0 \mathrm{mg} / \mathrm{m}^{3}$, diphenhydramine hydrochloride - ASLI $0.2 \mathrm{mg} / \mathrm{m}^{3}$, procaine hydrochloride - MAK $0.5 \mathrm{mg} / \mathrm{m}^{3}$, cyanocobalamin - MAK $0.05 \mathrm{mg} / \mathrm{m}^{3}$; in the atmospheric air: bismuth citrate - MAK $0.02 \mathrm{mg} / \mathrm{m}^{3}$, L-lysine aescinat - MAK $0.04 \mathrm{mg} / \mathrm{m}^{3}$, diphenhydramine hydrochloride - ASLI $0.006 \mathrm{mg} / \mathrm{m}^{3}$, procaine hydrochloride - MAK $0.01 \mathrm{mg} / \mathrm{m}^{3}$, cyanocobalamin - MAK $0.002 \mathrm{mg} / \mathrm{m}^{3}$. As a result of the sanitary-chemical researches the effect of the mentioned compounds in the working area and air of the inhabited places has been confirmed.

Key words: medicines, working area air, atmospheric air, regulation of the harmful influence. 